ISSN 0258-7122

Bangladesh J. Agril. Res. 38(2): 321-334, June 2013

\title{
THE IMPACT OF AGRICULTURAL EXTENSION CONTACT ON CROP INCOME IN BANGLADESH
}

\author{
ABU ZAFAR MAHMUDUL HAQ ${ }^{1}$
}

\begin{abstract}
The impact of extension contact on crop income is examined with a view to evaluating the agricultural extension in Bangladesh. The scope of the study was ten villages of Gazipur district. The objectives of the study are to i) determine the factors influencing the benefit of extension services in terms of farm income, ii) determine the factors affecting the extension contact of farmers, and iii) suggest some policy guidelines to improve the extension services in Bangladesh. The sample of the study consists of 1000 farmers. Data came from field survey and multistage random sampling technique was used in order to collect data. The results indicated that the impact of extension contact coefficient on crop income is positive and significant. Evidence shows that the influence of extension contact coefficient is strongly positive and significant in the comparatively nearer villages to upazila headquarters, while this effect is weaker for those villages, which are comparatively away from upazila headquarters. It is found that many farmers did not receive extension contact and the effect of extension contact is weak on crop income compared to other factors such as irrigation and chemical fertilizer. It is assumed that there was enough scope to increase extension contact in the study areas. Some determinants of extension contact were also examined. The study concludes that agricultural extension is necessary to increase among the farmers.
\end{abstract}

Keywords: Intercropping, HYV mustard, sugarcane, farmers’ fields.

\section{Introduction}

Realizing the importance of agricultural extension services, agricultural extension services have been increasing over time throughout the world (Owens et al, 2003). However, sometimes this is not adequately appreciated by most policymakers and planners in the less developed countries like Bangladesh. It is noted that agricultural extension services do not work satisfactorily and many farmers hardly ever received agricultural extension services in Bangladesh (Rayners and Bruening, 1996; Haq, 2004; Porimol et al., 2008; Daily Star, 2008; Haq, 2011b). This means that agricultural extension services in Bangladesh still fail to reach its ultimate goal, which is to increase the farmers' socio economic betterment. It is notable that agricultural extension services can provide farmers opportunities of productive works. As the socio economic improvement is one of

\footnotetext{
${ }^{1}$ Assistant Professor, Deptt. of Business Administration, City University, Banani, Dhaka 1213, Bangladesh. E-mail:zafarhaq34@gmail.com.
} 
the basic goals of agricultural extension, with the knowledge derived from agricultural extension services, a farm operator may raise his farm productivity.

Several studies were conducted by different authors considering several topics of agricultural extension (Haq et al., 2003; Jan et al., 2008; Haq, 2011a, b). Therefore, it is not easy to pinpoint the source of the difference in the previous studies because their data, location, objectives and model specifications were quite different. Haq et al. (2003) found that the extension contact had positive impact on the income of farmers. It is also depicted that higher income of farmers, young farmers and education of farmers are some key determinants of the extension contact. Results of Haq et al. (2003) recognized this impact, but it was unclear due to smaller samples and fewer study sites. More recently, Haq (2011a, b) examined the effects of extension contacts on the rice yield. The results are very much important because of large samples covering study sites.

One of the important objectives of the agricultural extension is to raise farmers' income. But the information of previous studies in this regard is scanty in order to evaluate agricultural extension. For example, whether or not the agricultural extension actually contributed among the farmers' productivity in terms of income and if yes, whether the benefits of the system are homogeneously distributed among the farmers have not been clarified enough. Investigating those issues toward developing further extension services that are more efficient is of prime importance. Therefore, the current study was conducted with the following major objectives: 1) to determine the factors influencing the benefit of extension services in terms of farm income; 2) to determine the factors affecting the extension contact of farmers, and 3) to suggest some policy guidelines to improve the agricultural extension in Bangladesh.

\subsection{Methodology}

\subsection{Sampling Design}

The selection of the Gazipur district, upazilas, villages and sample respondents were done purposively. There were some salient features in the selection procedure. First one, the selected district includes some important infrastructures, such as Bangladesh Agricultural Research Institute and Bangladesh Rice Research Institute, etc. Secondly, total number of selected villages was ten by selecting two villages from five upazilas. Of the two villages in each upazila, one village is selected comparatively near to the upazila headquarters and the other one is selected comparatively away from the upazila headquarters. The selected nearer villages were Samantapur (Sadar), Bagnahati (Sreepur), Dushya Narayanpur (Kapasia), Katalia (Kaliakoir), and Poinlanpur (Kaliganj). The selected villages which were comparatively away from the upazila headquarters, namely, Bara, Bhabanipur (Sadar), Saitalia (Sreepur), Noyanagar (Kapasia), 
Poshim Chandpur (Kaliakoir), and Bhatgati (Kaliganj). Thirdly, the total households were more than one hundred in the selected villages (BBS, 1993). It was then decided to collect one hundred ${ }^{2}$ samples from each village.

The total number of investigated farmers were one thousand (2 villages x 5 upazilas $\mathrm{x} 100$ farmers) and multistage random sampling technique was followed. Primary data was collected using survey method and personal interviews were conducted through pre-tested questionnaires with a view to collecting data. The survey was administered with the help of staff of BARI in 2002. Lastly, each upazila has some characteristics: Sadar upazila is completely urban type; Sreepur, Kapasia and Kaliganj upazilas are rural type and headquarters of these upazilas are the only urban areas, while Kaliakoir upazila headquarter is the only urban area and Safipur is the other urban area of this upazila (BBS, 1993).

\subsection{Empirical Model}

The model applied here is the input-output model. The heart of the input-output model is the concept of the production function [Y=f (Capital, Labour)] which helps us in understanding the role of important variables like capital and labour in determining the crop productivity. But only two factors have no reflection on the productivity of any crop. Therefore, based on related past studies (Evenson and Mwabu, 2001; Owens et al., 2003; Haq et al., 2003; Haq, 20011a,b) and logical analysis, some important explanatory variables are considered in this study namely age of the farm household head (Ag), number of family earners in the household (Fea), number of times extension contact received by the farmer for the sample crop season (Et), proportionate effect (\%) of flood to crop land (Fec), distance from farm land to market in miles (Mr), actual size of cultivated land in acre (Fs), per acre total cost of chemical fertilizer (Che), per acre total labour cost (Lab), per acre total money spent for irrigation (Irr), village dummy (Vdummy) $=1$ if near village; otherwise $=0$. Except for the variables of contact frequency, proportional effect of flood to crop land and village dummy, all the variables have been evaluated with a logarithmic converter to avoid disparities of the figures (Haq et al, 2003; Owens et al, 2003; Haq 2011a,b). Data have been analyzed by correlation and regression analyses. The productivity expressed in terms of crop income is as follows,

Ln Crop income = f( LnAg, Ln Fea, LnFs, Et, Fec, LnMr, Ln Lab, LnIrr, LnChe, Vdummy)....

\footnotetext{
${ }^{2}$ Data came from author's Ph.D Program.
} 
To understand the quantitative relationship individually between income of crop and the selected inputs namely extension contacts, irrigation, and chemical fertilizer, data were fitted with a linear regression model of the form:

$\mathrm{Y}=\mathrm{a}+\mathrm{bx}$, where $\mathrm{Y}=$ income of crop, $\mathrm{b}=$ coefficient of the input variable, $\mathrm{x}=$ relevant input and $\mathrm{a}=$ constant.

Crop income (rice and vegetables) is the dependent variable in the present paper as it is the major source of income in the sample farms. It has been calculated by deducting the total production costs from the gross return (Haq et $a l$, 2004). Gross return is the value of total production plus value of by products. Total cost are seed, manures, fertilizers, pesticides, irrigation, tractor, animal power, human labour, interest on capital and land rent as described in Haq et al, (2004). The value of subsistence and crops gifted to others is also included in net income, which is valued at prevailing local price (ibid).

In the objective of this research, the most important independent variable is that of the activities of the agricultural extension services. In Bangladesh Training \& Visit (T\&V) system, farmlands are divided into blocks and the T\&V workers target the representative farmers of the different blocks, who are referred to as "contact farmers"(Haq et al, 2003). Although the T\&V workers can directly get in touch with ordinary farmers, they mainly train the contact farmers, who afterwards transmit the training results to the other farmers, in a progressive system (ibid). Considering this situation in Bangladesh, the current paper used the frequency of contacts on the basis of actual number of times contacted between ordinary farmers and $\mathrm{T} \& \mathrm{~V}$ workers or contact farmers. Note that the combination of $\mathrm{T} \& \mathrm{~V}$ workers and contact farmers is hereinafter referred to as "extension agents" (ibid). Most of the farmers of Bangladesh are either illiterate or unskilled. Thus with the knowledge derived from extension services through extension contact, farm operators may increase their income (Haq et al., 2003; Owens et al., 2003).

Similarly, a farmer's extension services may be influenced by many factors. In one sense, the extension services may be considered as further education; thus educated farmers may be willing to receive this support service. Extension services provide technology and information, thus age may be an important determinant for acquiring extension contacts. Farm families should increase their earning sources if they want to use extension knowledge. For this reason, increasing the number of family earners may be one of the best ways for a farm family to receive extension support.

Relevant importance of other selected variables such as number of family members, farm size, irrigation, labour, chemical fertilizer and distance between farm land and nearest market place, villages near to urban areas and distant villages can be found in related literatures (Haq, 2004; Evenson and Mwabu, 
2001). In this paper, the number of contacts was considered as a dummy variable and then the Binary Logit was adopted (Haq, 2011c) to identify the contact frequency function considering the nature of the data, thus,

Et dummy = f (LnAg, Ed, LnFs, LnFea, LnFm, LnMr, LnChe, LnIrr, Vdummy, Udummy)...(3).

Where Et dummy = extension contact receive 1, otherwise 0,

$\mathrm{Ag}=$ age of the farm household head, Ed=years of schooling of the farm household head, Fs=actual size of cultivated land in acre, Fea=number of family earners in the household, Fm=number of family members in a farm family, $\mathrm{Mr}=$ distance from farm land to market in miles, Che $=$ per acre total cost of chemical fertilizer, Irr = per acre total money spent for irrigation, village dummy (Vdummy) $=1$ if near village; otherwise $=0$ and upazila dummy (Udummy) i.e. Sadar upazila $=1$, otherwise $=0$.

Table 1. presents summary statistics of variables included in the models for further references.

Table 1. Summary statistics of variables.

\begin{tabular}{llll}
\hline \multicolumn{1}{c|}{ Variables } & \multicolumn{1}{c}{ Mean } & \multicolumn{1}{c}{$\begin{array}{c}\text { Standard } \\
\text { Deviation }\end{array}$} \\
\hline Crop income (Taka) & 13338.04 & 11387.51 \\
Ag (Age of the farm household head) & 42.52 & 11.83 \\
Ed (Schooling years of farm household head) & 5.77 & 2.11 \\
Fm (Number of family members in the household) & 5.34 & 2.11 \\
Fea(Number of family earners in the household) & 1.49 & 0.85 \\
Et (Number of times extension contact) & 0.24 & 0.61 \\
Fs (actual size of cultivated land in acre) & 0.74 & 0.61 \\
Fec (Proportionate effect of flood to crop land) & 10.08 & 19.79 \\
Mr (Distance from farm land to nearest market in miles) & 1.03 & 1.39 \\
Che (Per acre total cost of chemical fertilizer) & 6719.25 & 17927.92 \\
Irr (Per acre total cost of irrigation) & 6377.12 & 17415.85 \\
Lab (Per acre total cost of labour) & 7025.70 & 18513.73 \\
Vdummy (1 near village; otherwise 0) & 0.50 & 0.50 \\
Udummy (Sadar upazila 1; otherwise 0) & 0.10 & 0.10 \\
\hline
\end{tabular}

Source: Haq, 2004. Haq et al., 2004. 


\subsection{Results and Discussion}

\subsection{Multivariate analysis}

It is argued that a correlation analysis is necessary to identify the degree of association between the dependent and selected independent variables in order to determine their expected signs prior to multivariate analysis (Evenson and Mwabu, 2001). A correlation analysis is done and Table 2 demonstrates the possible signs of selected numerous factors which can affect on the income of crop. The positive signs of the correlation coefficients of most of the included variables imply that selected variables will contribute positively and the negative signs in some variables imply declines in the income of crop in the study areas.

Table 2. Correlation coefficients of the variables.

\begin{tabular}{l|l|l}
\hline \multicolumn{1}{c|}{ Variables } & $\begin{array}{c}\text { Correlations } \\
\text { with crop } \\
\text { income }\end{array}$ & P-values \\
\hline Age of the farm household head & -0.025 & 0.422 \\
Number of family members in the household & $0.151^{* * *}$ & 0.000 \\
Number of family earners in the household & $0.160^{* * *}$ & 0.000 \\
Number of times extension contact & 0.031 & 0.328 \\
Proportionate effect of flood to crop land & $-0.096 * * *$ & 0.002 \\
Distance from farm land to nearest market in miles & $-0.088^{* * *}$ & 0.005 \\
Per acre total cost of chemical fertilizer & $0.0460 * * *$ & 0.000 \\
Per acre total cost of irrigation & $0.331 * * *$ & 0.000 \\
Per acre total cost of labour & 0.049 & 0.124 \\
Village dummy & $-0.134 * * *$ & 0.000 \\
\hline
\end{tabular}

*** indicate $1 \%$ level of significance.

The estimated values of coefficients and related statistics of the multiple regression coefficients of villages are presented in Table 3. These results are almost similar to the correlation results. The adjusted $\mathrm{R}^{2}$ values are low and agree with similar studies which are understandable because of the numerous factors affecting the income of crop (Haq, 2004). The F-values are significant at $1 \%$ level of significance which implies that the specifications of the models were reasonably accurate (Haq, 2011a,b).

Table 3 shows that the coefficient for contact of the nearer villages is particularly great $(0.110)$ compared to the villages away from the upazila headquarters (0.025). According to Owens et al. (2003), a frequency of one and 
two operations per year between extension agents and farmers generates a high contribution to yield. However, a frequency of three or more than three times per year showed no clear effects in his study. Compared with the results of Owens et al. (2003) the results of Haq et al. (2003) suggests that in Bangladesh, the higher number of contacts ( 3 contacts or more per year) between extension agents and farmers seem more effective in order to raise income of crop. Haq et al. (2003) found that the extension contact coefficient for 3 contacts or more per year on crop income was 0.353 , while the coefficient for 1-2 contacts per year on crop income was 0.234 .

The present analysis suggests that in Bangladesh, the higher number of contacts between extension agents and farmers seem more effective in the case of nearer villages with minor exception in order to increase crop income. Conversely, no such clear effects are found in the comparatively far villages since their coefficients are mostly insignificant. Similarity is also observed in the case of the effects of extension contact on rice yield (Haq, 2011b). Haq (2011b) observed that the coefficient for contact $(0.116)$ was stronger in the progressive villages than in the less progressive villages (0.064). Jan et al. (2008) observed that the coefficient for contact was stronger in the well situated villages.

The more higher number of contacts are plausible because the farmers who have more than three contacts could get case - by - case suitable guidance encouraging the application of fertilizers or prevention of insects and diseases etc.( Haq et al., 2003). Accordingly, it is possible to ascertain in the context of all villages that the contacts with extension agents contributed to increase the income of crop of farmers.

The results of the functional analysis suggest that most of the variables had a positive effect on income in the sample farms except for few variables other than the coefficient of the extension contact.

Flood (Fec) has significant impact on the income of crop. It implies that crop income decreases as floods increase.

The coefficient of distance between market and nearest crop land (Mr) has negative but statistically significant effects. It means that greater the distance from the farm land to the nearest market is, the lower the income is.

The effect of irrigation (Irr) costs is significantly negative. It implies that to get higher crop income, it is not necessary to spend excess money for irrigation. Vdummy has negative and statistically significant impact, it means that the progressive villagers are able to get higher income from crop. 


\begin{tabular}{|c|c|c|c|c|c|c|c|c|c|c|c|c|c|}
\hline Variables & Samantapur & Bagnahati & $\begin{array}{c}\text { Dushya } \\
\text { Narayanpur }\end{array}$ & Katalia & Poilanpur & \begin{tabular}{|c} 
All \\
Near \\
Villages
\end{tabular} & $\begin{array}{c}\text { Bara } \\
\text { Bhabanipur }\end{array}$ & Saitalia & Noyanagar & $\begin{array}{l}\text { Poshim } \\
\text { Chandpur }\end{array}$ & Bhatgati & $\begin{array}{l}\text { All Far } \\
\text { Villages }\end{array}$ & $\begin{array}{c}\text { All } \\
\text { Villages }\end{array}$ \\
\hline LnFea & $\begin{array}{l}.005 \\
.051\end{array}$ & $\begin{array}{l}.059 \\
.596\end{array}$ & $\begin{array}{l}-.107 \\
-.942\end{array}$ & $\begin{array}{l}-.040 \\
-.403\end{array}$ & $\begin{array}{l}.100 \\
.938\end{array}$ & $\begin{array}{l}.016 \\
.344\end{array}$ & $\begin{array}{l}.156^{* *} \\
1.603\end{array}$ & $\begin{array}{l}-.018 \\
-.174\end{array}$ & $\begin{array}{l}.121^{*} \\
1.160\end{array}$ & $\begin{array}{l}.058 \\
.509\end{array}$ & $\begin{array}{l}.014 \\
.091\end{array}$ & $\begin{array}{l}.055^{*} \\
1.138\end{array}$ & $\begin{array}{l}.030 \\
.918\end{array}$ \\
\hline Et & $\begin{array}{l}.129 * \\
1.335\end{array}$ & $\begin{array}{l}.196 * \\
1.586\end{array}$ & $\begin{array}{l}-.053 \\
-.493\end{array}$ & $\begin{array}{l}-.017 \\
-.164\end{array}$ & $\begin{array}{l}.026 \\
.252\end{array}$ & $\begin{array}{l}.110^{* *} \\
2.353\end{array}$ & $\begin{array}{l}.094 \\
.962\end{array}$ & $\begin{array}{l}.074 \\
.431\end{array}$ & $\begin{array}{l}-.070 \\
-.418\end{array}$ & $\begin{array}{l}.102 * \\
1.008\end{array}$ & $\begin{array}{l}.126 \\
.997\end{array}$ & $\begin{array}{l}.025 \\
.485\end{array}$ & $\begin{array}{l}.070 * * \\
2.061\end{array}$ \\
\hline Fec & $\begin{array}{l}-.366 * * * \\
-3.812\end{array}$ & $\begin{array}{l}.265^{* *} \\
1.792\end{array}$ & $\begin{array}{l}-.176^{* *} \\
-1.407\end{array}$ & $\begin{array}{l}.445^{* * * *} \\
3.783\end{array}$ & $\begin{array}{l}.107^{*} \\
1.056\end{array}$ & $\begin{array}{l}.112^{* *} \\
2.385\end{array}$ & $\begin{array}{l}-.181^{* *} \\
-1.760\end{array}$ & $\begin{array}{l}-.042 \\
-.216\end{array}$ & $\begin{array}{l}-.093 \\
-.488\end{array}$ & $\begin{array}{l}.355^{* * * *} \\
3.127\end{array}$ & $\begin{array}{l}-.170 * \\
-1.002\end{array}$ & $\begin{array}{l}.024 \\
.448\end{array}$ & $\begin{array}{l}.079 * * \\
2.284\end{array}$ \\
\hline $\mathrm{LnMr}$ & $\begin{array}{l}-.289 * * \\
-2.755\end{array}$ & $\begin{array}{l}.316^{* *} \\
2.685\end{array}$ & $\begin{array}{l}.027 \\
.230\end{array}$ & $\begin{array}{l}-.250 * * \\
-2.392\end{array}$ & $\begin{array}{l}-.260 * * \\
-2.450\end{array}$ & $\begin{array}{l}-.086^{*} \\
-1.794\end{array}$ & $\begin{array}{l}-.262 * \\
-2.621\end{array}$ & $\begin{array}{l}-.080 \\
-.633\end{array}$ & $\begin{array}{l}-.025 \\
-.203\end{array}$ & $\begin{array}{l}-.237 * * \\
-2.474\end{array}$ & $\begin{array}{l}.383^{* *} \\
1.586\end{array}$ & $\begin{array}{l}-256 * * * \\
-5.349\end{array}$ & $\begin{array}{l}-176^{* * *} \\
-5.078\end{array}$ \\
\hline LnIrr & $\begin{array}{l}.004 \\
.035\end{array}$ & $\begin{array}{l}-.039 \\
-.380\end{array}$ & $\begin{array}{l}-.181^{* *} \\
-1.638\end{array}$ & $\begin{array}{l}-.152^{*} \\
-1.022\end{array}$ & $\begin{array}{l}-.106 * \\
-1.011\end{array}$ & $\begin{array}{l}-.090 * * \\
-1.729\end{array}$ & $\begin{array}{l}.181^{* *} \\
1.608\end{array}$ & $\begin{array}{l}-.100 \\
-.994\end{array}$ & $\begin{array}{l}.171^{* *} \\
1.723\end{array}$ & $\begin{array}{l}-.200 * * \\
-1.744\end{array}$ & $\begin{array}{l}-.017 \\
-.124\end{array}$ & $\begin{array}{l}-.053^{*} \\
-1.065 \backslash\end{array}$ & $\begin{array}{l}-.069 * * \\
-1.959\end{array}$ \\
\hline LnChe & $\begin{array}{l}-.004 \\
-.031\end{array}$ & $\begin{array}{l}-.280 * * \\
-2.171\end{array}$ & $\begin{array}{l}.070 \\
.507\end{array}$ & $\begin{array}{l}.194 * \\
1.223\end{array}$ & $\begin{array}{l}-.058 \\
-.402\end{array}$ & $\begin{array}{l}0.22 \\
.397\end{array}$ & $\begin{array}{l}-.215^{* *} \\
-1.729\end{array}$ & $\begin{array}{l}.126 \\
.951\end{array}$ & $\begin{array}{l}-.411 * * * \\
-3.135\end{array}$ & $\begin{array}{l}.029 \\
.195\end{array}$ & $\begin{array}{l}-.001 \\
-.011\end{array}$ & $\begin{array}{l}-.031 \\
-.541\end{array}$ & $\begin{array}{l}.024 \\
.630\end{array}$ \\
\hline Vdummy & --------- & ---- & --- & --- & ---- & --- & ----- & ----- & ---- & ---- & -------- & ---- & $\begin{array}{l}-135 * * * \\
-3.925\end{array}$ \\
\hline $\begin{array}{l}\mathrm{AR}^{2} \\
\mathrm{~F} \\
\mathrm{~N} \\
\end{array}$ & $\begin{array}{c}.166^{* * *} \\
3.186 \\
99 \\
\end{array}$ & $\begin{array}{l}.141^{* *} \\
2.802 \\
99 \\
\end{array}$ & $\begin{array}{l}.005^{*} \\
1.061 \\
99 \\
\end{array}$ & $\begin{array}{l}.157 * * * \\
3.014 \\
97 \\
\end{array}$ & $\begin{array}{l}.066^{* *} \\
1.774 \\
98 \\
\end{array}$ & $\begin{array}{l}.045^{* * *} \\
3.612 \\
492 \\
\end{array}$ & $\begin{array}{l}.153^{* *} \\
2.971 \\
99 \\
\end{array}$ & $\begin{array}{l}.106^{* *} \\
2.307 \\
99 \\
\end{array}$ & $\begin{array}{l}.132 * * \\
2.666 \\
99 \\
\end{array}$ & $\begin{array}{l}.149 * * \\
2.866 \\
96 \\
\end{array}$ & $\begin{array}{l}.177^{* * *} \\
3.708 \\
64 \\
\end{array}$ & $\begin{array}{l}.064^{* * * *} \\
4.492 \\
457 \\
\end{array}$ & $\begin{array}{l}-.3925 \\
.068^{* * *} \\
7.932 \\
949 \\
\end{array}$ \\
\hline
\end{tabular}




\subsection{Individual effects}

It is found (Table 4) that the use of extension contact resource is particularly higher $\left(\mathrm{R}^{2}=5.5 \%\right)$ in the progressive villages compared to the non-progressive villages $\left(R^{2}=0.2 \%\right)$. Compared with irrigation and chemical fertilizer, extension contact and crop income showed a low degree of association $\left(\mathrm{R}^{2}=1.00 \%\right)$ in all villages as it evidenced from the results of Table 4. It is assumed that there is enough scope to increase the extension contact since only 1 percent extension contact resource has been utilized. Similarity is also observed in many investigations (Haq et al., 2003; Rafiqul, 2009). In practice, one extension worker in Bangladesh covers 1000 to 1200 households, while it covers 235 households in Japan (Hoque et al., 2004). Thus extension workers in Bangladesh cannot transfer relevant ideas about farm management to all farmers appropriately; they rather tend to reach the farmers of some specific areas and probably, assist literate farmers (Table 5).

Table 4. Effects of extension contact, irrigation and chemical fertilizer on crop income.

\begin{tabular}{|c|c|c|c|}
\hline \multirow[t]{4}{*}{ Effect of extension contact: } & \multicolumn{3}{|c|}{ (Best fit regression equation: Lncrop income=a+bEt) } \\
\hline & Progressive villages & $8.93+0.323 \mathrm{Et}$ & R-Square 5.5\% \\
\hline & $\begin{array}{l}\text { Non Progressive } \\
\text { villages }\end{array}$ & $9.35-0.0565 E t$ & R-Square $0.2 \%$ \\
\hline & All villages & $9.14+0.129 \mathrm{Et}$ & R-Square 1.0\% \\
\hline \multirow[t]{4}{*}{ Effect of irrigation : } & \multicolumn{3}{|c|}{ (Best fit regression equation: $\mathrm{Ln}$ crop income $=\mathrm{a}+\mathrm{bLnIrr}$ ) } \\
\hline & Progressive villages & 2.29+2.99Irr & R-Square $22.1 \%$ \\
\hline & $\begin{array}{l}\text { Non Progressive } \\
\text { villages }\end{array}$ & $-0.539+4.32 \operatorname{Irr}$ & R-Square $27.3 \%$ \\
\hline & All villages & 1.29+3.48Irr & R-Square $24.7 \%$ \\
\hline \multirow[t]{4}{*}{ Effect of chemical fertilizer : } & \multicolumn{3}{|c|}{$\begin{array}{l}\text { (Best fit regression equation: Ln crop } \\
\text { income=a+bLnChe) }\end{array}$} \\
\hline & Progressive villages & 1.72+9.02Chem & R-Square $29.8 \%$ \\
\hline & $\begin{array}{l}\text { Non Progressive } \\
\text { villages }\end{array}$ & 1.61+9.37Chem & R-Square $26.3 \%$ \\
\hline & All villages & 1.45+9.45Chem & R-Square $30.1 \%$ \\
\hline
\end{tabular}

Source: Author's calculation from survey data. 
Table 5. Extension contact by literacy and village levels (number of farmers).

\begin{tabular}{clll|l}
\hline & $\begin{array}{c}\text { Extension contact } \\
\text { received }\end{array}$ & \multicolumn{1}{|c}{$\begin{array}{c}\text { No extension } \\
\text { contact }\end{array}$} & Total \\
\hline Near villages & & & \\
Literate & $102(10.20)$ & $352(35.2)$ & $454(45.4)$ \\
Illiterate & $06(0.60)$ & $40(4.0)$ & $46(4.6)$ \\
Total & $108(10.80)$ & $392(39.2)$ & $500(50)$ \\
Far villages & & & \\
Literate & $62(6.2)$ & $398(39.8)$ & $460(46.0)$ \\
Illiterate & $01(0.10)$ & $39(3.9)$ & $40(4.0)$ \\
Total & $63(6.3)$ & $437(43.7)$ & $500(50)$ \\
All villages & & & \\
Literate & $164(16.40)$ & $750(75.0)$ & $914(91.4)$ \\
Illiterate & $07(0.70)$ & $79(7.9)$ & $86(8.6)$ \\
Total & $171(17.1)$ & $829(82.9)$ & $1000(100)$ \\
\hline
\end{tabular}

Figures in the brakets indicate percent of farmers.

Source: Survey data.

\subsection{Frequency of the contacts with extension agents}

What kind of factors determine the frequency of contact between farmers and the extension agents, clarifying this point is extremely important to promote more effective agricultural extension activity. A correlation analysis has been employed to identify the important factors associated with the extension contacts. It is seen in Table 6 that Ed, Fea, Fm, Irr, Vdummy variables are expected to be closely associated with the extension contact, while Ag, Fs, Mr, Che, Udummy variables have no direct association with the extension contact. The estimated results of the logit function, based on formula (3), are presented in Table 7. As appear in Table 7, the survey farms that fulfilled the following conditions have had frequent contacts with the extension agents:

The coefficient for cultivated area (Fs) is -0.440 , which is negative but significant at the 1 percent degree of probability. It implies that one percent increase in the total cultivated land, the probability of extension contact will be decreased by $44.0 \%$.

The coefficient for the number of earners in a farm family (Fea) is - 0.443 and is significant at the 5 percent degree of probability. It can be said that farm households' heads with low dependency on the number of earners in the farm families, have increasing dependency on extension contacts. 
The coefficient for the distance between farm land and nearest market place (Mr) is not positive

$(-0.334)$ but highly significant. It implies that the greater the distance from the farm land to the nearest market is, the lower the extension contact is and vice versa.

The coefficient for the cost of chemical fertilizer (Che) per unit of farm land is positive (85.94) and significant. Thus it can infer that households hoping to increase the use of chemical fertilizer per unit of land may likely to get extension contact. It is seen that the coefficient for irrigation expenditure per unit of farm land (Irr) is not positive but significant. It implies that the relationship between extension contact and irrigation is inverse.

The coefficient for the village dummy (Vdummy) is positive and significant. It means that extension contacts are particularly higher in the progressive villages compared to the less progressive villages. The coefficient for the upazila dummy (Udummy) is negative (-1.95) but significant. It can be concluded that there is no direct relationship between upazila dummy and extension contact.

Table 6. Correlation analyses between the selected independent variables and extension contact.

\begin{tabular}{|c|c|c|c|c|c|}
\hline $\begin{array}{l}\text { Dependent } \\
\text { variable }\end{array}$ & $\begin{array}{c}\text { Independent } \\
\text { variables }\end{array}$ & $\begin{array}{l}\text { Correlation } \\
\text { coefficient }\end{array}$ & $\begin{array}{l}\text { Calculated } \\
\text { values }\end{array}$ & $\begin{array}{l}\text { Tabulated } \\
\text { values }^{1}\end{array}$ & $\begin{array}{c}\text { Significance } \\
\text { level }\end{array}$ \\
\hline \multirow{10}{*}{ Et } & $\mathrm{Ag}$ & -0.012 & 0.704 & 0.254 & 0.01 \\
\hline & Ed & 0.047 & 0.142 & 0.164 & ns \\
\hline & Fs & -0.125 & 0.000 & 0.254 & 0.01 \\
\hline & Fea & 0.025 & 0.445 & 0.254 & 0.05 \\
\hline & $\mathrm{Fm}$ & 0.029 & 0.372 & 0.254 & 0.05 \\
\hline & $\mathrm{Mr}$ & -0.038 & 0.242 & 0.195 & 0.05 \\
\hline & Che & -0.047 & 0.142 & 0.164 & ns \\
\hline & Irr & 0.133 & 0.000 & 0.254 & 0.01 \\
\hline & Vdummy & 0.104 & 0.001 & 0.254 & 0.01 \\
\hline & Udummy & -0.088 & 0.006 & 0.254 & 0.01 \\
\hline
\end{tabular}

Source: Haq (2011b); ${ }^{1}$ Mahajan 1997. 
Table 7. Binary logistic regression.

\begin{tabular}{lllll}
\hline \multicolumn{1}{c}{ Variables } & \multicolumn{1}{c}{ Coefficient } & \multicolumn{1}{c}{ SE Coef } & \multicolumn{1}{c}{ P-Values } \\
\hline Constant & 5.840 & 6.340 & 0.357 \\
Ln Ag & -0.318 & 0.359 & 0.374 \\
Ed & 0.002 & 0.002 & 0.935 \\
LnFs & -0.440 & 0.191 & 0.021 \\
Ln Fea & -0.443 & 0.228 & 0.052 \\
LnFm & 0.005 & 0.041 & 0.902 \\
LnMr & -0.334 & 0.123 & 0.007 \\
Ln Che & 85.94 & 28.498 & 0.003 \\
Ln Irr & -34.02 & 12.706 & 0.007 \\
Vdummy & 0.855 & 0.196 & 0.000 \\
Udummy & -1.947 & 0.411 & 0.000 \\
Log-Likelihood & $-380.869, \mathrm{~N}=949$ & &
\end{tabular}

Dependent variable: Extension contact (if yes 1, otherwise 0).

\subsection{Conclusion and Recommendations}

This paper aimed at clarifying the effects of agricultural extension services on improving the productivity of farmers with the example of one district of Bangladesh, emphasizing the relevance of number of times extension contacts between farmers and extension agents. The results of the study can be stated as follows:

First, from the estimated production function, it is clarified that the more the extension contacts between extension agents and farmers, the higher the income is. This clarifies that the extension contact has positive and significant effects in improving farm income. The effect of extension contact is stronger in the nearer villages to upazila headquarters. It is also found that many farmers did not receive extension contact and the effect of extension contact is weak on crop income compared to other factors such as irrigation and chemical fertilizer. For this, it can be clarified that agricultural extension services do not work well and there is enough scope to increase the extension contact.

Second, by examining the factors determining the contacts between extension agents and farmers, a positive association was found with the level of education, size of farm families, chemical fertilizer and villages which are comparatively near to the upazila headquarters. On the other hand, the size of farm, age of the farm household head, distance between farm land to nearest market, irrigation and upazila dummy variables have no direct relationship with the extension agents. 
Considering the overall estimation, it has been possible to ascertain that agricultural extension services positively contribute to increasing the crop income of farmers to some extent, but there is a necessity to develop the system toward more efficiency for all farmers in Bangladesh. In this context, following proposals can be helpful for the policy formulation:

1. Sub assistant agricultural officers (SAAOs) of the agricultural extension services should be increased in order to spread extension contact among the farmers.

2. Illiterate farmers should be given top priority for the acceleration of extension contact. Extension contact will assist them to conduct agricultural works effectively.

3. Infrastructure development, such as roads, markets in the rural areas are necessary to construct because these infrastructures can increase communication between extension agents and farmers.

4. Irrigation is very important for the cultivation of winter crops. It is noted that the average knowledge of irrigation in the farmers of Bangladesh is very poor (Porimol, 2008). Similarly, it is also observed that the relationship between irrigation and extension contact is not desirable in the present study area. Therefore, it is necessary to increase extension contact in order to transmit the appropriate knowledge of irrigation among the farmers.

As a final comment, since the Bangladesh Government has given top priority for the development of agriculture in Bangladesh, agricultural extension is necessary to increase among the farmers.

\section{References}

Begum, R. 1998. An economic study of wheat production and marketing in Bangladesh. Diss. Ehime University, Japan.

BBS.1993. Bangladesh Bureau of Statistics. Ministry of Planning, GOB.

Birkhaeuser, D. and R. E. Evenson. 1991. The economic impact of agricultural extension: A review. Econ. Deve. \& Cul. Chan. 39(1):607-650.

Daily Star.2008. Pest attack affects Aman paddy yield in Netrokona, Patuakhali. Oct. 19. Pp.14.

Evenson, R.E and G. Mwabu. 2001. The effect of agricultural extension on farm yields

Kenya. African Deve. Rev. 13(1):1-23.

Haq, A.Z.M., K. Taniguchi and A.Ishida. 2004. The impact of farmers' education on income in Bangladesh. J. of the Japanese Soci. of Agric. Tech. Mg. 11 (1): 13-21.

Haq, A. Z. M., A. Ishida, S.Yokoyama and K.Taniguchi. 2003. Outcomes and issues of agricultural extension services in Bangladesh. J. of Agric. Ext. Res. 8(17): 17- 22. 
Haq, A. Z. M. 2004. The role of farmers' education and agricultural extension services in Bangladesh. Diss. Tottory University, Japan.

Haq, A. Z. M. 2011a. Effect of extension contact on rice yield in Gazipur District of Bangladesh. Proceedings of the $4^{\text {th }}$ EuroMeD Academy of Business Annual Conference, October $20^{\mathrm{th}}-21^{\text {st }}$ Elounda, Crete, Greece. Pp. 766-776.

Haq, A. Z. M. 2011b. Effect of extension contact on rice productivity in some selected sites of Gazipur District. Bangladesh J. of Agric. Res. 36 (4):723-732.

Haq, A. Z. M. 2011c. Outcomes and issues of farmers' education on rice productivity in Bangladesh. Proceedings of the annual conference HR at the modern workplace 1617 December, SDM institute for management development, Mysore, India (CD version).

Hoque, J. M and K. Usami. 2004. Comparative study on agricultural extension work between Bangladesh and Japan: the view point of skill formation. The J. of Rul. Prob.40 (1):122-126.

Jan, I. N. Khan and S. N. Shaukat. 2008. Econometric analysis of the determinants of participation in agricultural extension services: An example from Pakistan. J. of Ext. Sys. 24(1): 63-75.

Mahajan, B. K. 1997. Bio Statistics: $6^{\text {th }}$ ed. Jaypee Brothers, India.

Ownes, T., Hoddinott and B. Kinsey. 2003. The impact of agricultural extension on farm production resettlement areas of Zimbabwe. Econ. Dev. \& Cul. Chan. 51(2): 337357.

Porimol, P. 2008. Rice yield to leap on less irrigation. Reveals BADC Study. Daily Star, June 22. P. 1.

Porimol,P., R.Sarker and A. Islam .2008. New Rice varieties smile at monga hit people. Daily Star, Octo.15. P.14.

Rafiqul,I. 2009. Betel leaf growers in south left in peril. Daily Star, May 11. P. 1.

Reynar, R and T.Bruening. 1996. Agricultural extension issues: perception of Bangladesh T\&V extension personnel. J. of Int. Agric. \& Ext. 3(1):53-62. 